\title{
Introduction
}

\section{MEDICAL HISTORIOGRAPHY}

Until recently, the field of medical history was a specialization of medicine rather than of history. The topics were mostly written by, for and about doctors. Then in the second half of the twentieth century, a shift took place. A new generation of medical historians in the Anglo-Saxon world broke with the traditional orientation to standard medicine and made space for alternative medicine and its practitioners. The focus moved to the societal context of medical care. Henri Sigerist, a Swiss who had moved to the USA, introduced the patient into medical history. He is considered the originator of the new American social history movement (Huisman 1995:144-5). The essay by Susan Reverby and David Rosner from 1979, 'Beyond the "Great Doctors", is held to be the manifesto of this movement (Huisman and Warner 2004:21).

For historians, anthropologists and sociologists this development was interesting, but many traditional medical history writers in the AngloSaxon world, primarily physicians, were not comfortable with topics that were not purely medical and written by academics who were not doctors. The editorial comment in the fournal of the History of Medicine (January 1980) spoke of a 'medical history without medicine' (Reverby and Rosner 2004:174). In the Netherlands, G.A. Lindeboom, the éminence grise of the Dutch history of medicine, feared that the new generation would have too little respect for physicians (Huisman 1995:134). This concern reflected the loss of status of medicine and its practitioners in the 1960s and 1970s. Even in the professional group itself, a new wind was blowing: the British professor of social medicine, Thomas McKeown, questioned the conviction of many of his colleagues that better medical care and medicines had spectacularly extended the average life expectancy and 
ascertained that more and better food, hygiene and birth control were far more important. ${ }^{1}$

That the fear of a 'takeover' of medical historiography by non-medical historians was unfounded was demonstrated by Olga Amsterdamska and Anja Huizing in an analysis of articles in three medical journals (Bulletin of the History of Medicine, fournal of the History of Medicine and Allied Sciences and Medical History) from the period 1960-2001. It is true that the number of authors with a strictly medical background had declined from 50\% in 1960-1961 to only $13 \%$ in 2000-2001. The number of historians increased proportionally from $47 \%$ to $78 \%$. Amsterdamska and Huizinga based their research solely on the titles of the articles and ascertained that they contained less spectacular shifts than would have been expected given the changed background of the authors. They preferred to talk of diversification rather than a radical change in themes. In addition, it was apparent that primarily prestigious medical journals such as The Lancet cited articles from those three journals and the periodical Social History of Medicine. Evidently, although the authors of medical history were no longer all doctors, their articles were still read by doctors. This suggested to Amsterdamska and Huizing an explanation for the traditional orientation and isolation of the medical history field compared with other sciences (Amsterdamska and Huizing 2004:241-3, 259).

\section{THE MEDICAL MARKET}

In recent medical-historical research, the concept of the 'medical market' has become widespread. Some claim this concept was introduced concurrently about 1985 by various English-speaking scholars; ${ }^{2}$ others ascribe the honour to Harold Cook. ${ }^{3}$ Medical treatments are indicated by the metaphor of supply and demand on the medical market. Researchers started exploring outside the boundaries of scientifically based medical care; the alternative forms of treatment were also being covered. In addition, the role of the care recipient came to the fore, along with the many socio-cultural and socio-economic factors determining supply and demand.

\footnotetext{
In his book, The role of medicine: Dream, mirage or nemesis? (1976), Jansen 1982:91.

Jenner and Wallis 2007:1 cite Lucinda Beier, Roy Porter, Irvine Loudon and Harold Cook.

Gentilcore 1998:2; Pelling 2003:2, 342-3.
} 
From the perspective of the demand side of care - the patients - the medical market is the entirety of available consultation and treatment options, varying from self-care, the intervention of a supernatural force to consulting a professional practitioner. The care recipients are driven by medical, emotional, economic or other motives when selecting a practitioner. They are active, participating in 'healer shopping', sometimes out of desperation, sometimes as critical consumers. Their ideas and concepts of health, disease and the environment influence their behaviour.

From the supply side's perspective - the practitioners - the market model focuses on popularity and competition. With a view to competition, it can be beneficial to spot gaps in the market and to specialize:

\begin{abstract}
Fractures, teeth, eye, smallpox and plague specialists, lithotomists, bonesetters, cataract surgeons, but also herbalists, chemists and certain apothecaries literally filled a hole in the market more or less consciously neglected by the established physicians due to the level of technical difficulty, danger to the patient's or physician's life, or even corporate reasons. ${ }^{4}$
\end{abstract}

It appears that regular practitioners in those days sometimes avoided risky treatments to keep their reputation unblemished and thus their competitive position with the irregular practitioners. The 'group' of irregulars is so heterogeneous that there cannot be any question of a joint reputation to uphold. An important weapon in the struggle for supremacy was maligning the competition. The regular physicians in the Netherlands called the irregulars 'quacks'. In turn, the dukun, the irregular, indigenous healers, invented all kinds of claims about the regulars, for example, that the smallpox vaccination was intended solely to pressgang troops for the Indies army. ${ }^{5}$

\title{
THE MEDICAL MARKET MODEL: A WORN CONCEPT?
}

Mark S.R. Jenner and Patrick Wallis (2007:1-24) were very critical about the concept of the 'medical market'. They observed that it has become

\footnotetext{
4 Chaudron 1995:11. The quotation is taken from Willem Frijhoff.

5 'When the vaccination was introduced in the Priangan, a rumour circulated that this was a "Company brand", that every boy who was so "marked" had to serve as a soldier later. For a brief while there was tension, and many fled into the jungle according to Holle', Van den Berge 1998:170.
} 
amazingly popular and has an enormous diversity of applications. The model has many merits: It removed the almost mystical status from the medical profession, secured a place for medical laypeople, and considered patients as consumers of medical services. Some historians objected that the concept leaves little room for cultural and social factors. As it has been used in several different ways, it is thought to have lost its expressiveness and sometimes even become confusing. Perhaps it would be better to stop using the concept of the 'medical market', but given its popularity Jenner and Wallis feel this is not feasible. They would prefer to substitute 'markets for medical goods and services' for the popular and generalizing term 'medical market', as it better matches the variety of social and economic networks involved. A good term should reflect not only individual providers and consumers but also the institutional ones. For brevity's sake and because of popular use every now and then 'medical market' will be used in this book.

\section{THE MEDICAL MARKET MODEL IN THE COLONIES}

The concept of the 'medical market' has almost never been applied to a colonial society, which is by definition plural in composition. This was certainly true of the Dutch East Indies, a vast archipelago with circa 20 million inhabitants in 1850 with varied languages and cultures, all differing drastically from the ruler's. J.A.A. van Doorn (1982:130, 1994:52-3) considers mediation vital in every plural society; and given the social and cultural distances between the groups, intermediaries are required for communication. On the medical market as well, an intermediary is required between care consumers and care providers to 'translate' the social-cultural factors involved in the 'negotiation process' between patient and practitioner.

In every society, socio-cultural factors influence the social traffic between individuals and groups. If the diversity of the population groups is large, as in the colonial Dutch East Indies, the diversity of socio-cultural factors will be similarly broad. These factors are involved in the medical market in the communication between care consumers and care providers. They determine to a certain extent the 'interaction' between supply and demand and are therefore to be considered 'rules of the game'. 


\section{SOURCES}

Sources can be used in different ways. They not only provide facts, they proffer insight into the selection an author makes from all the available data and thus into his/her underlying motives. The status of the source is also informative. The dokter djawa school and the midwives' school that are the subject of this book were given from the start their own section in the Colonial Report (Koloniaal Verslag), the official document that the minister of Colonies submitted each year to Parliament. The costs for the two schools were not especially high; therefore, other - political considerations must have dictated reserving so much space for them in this important document.

Most sources covering the colonial period in the Dutch East Indies were written in Dutch, English, Malay and Javanese; unfortunately, I do not understand Javanese. Here, primarily the Dutch sources are used, mainly official documents written by European men. We must be aware that they communicate a one-sided picture. In his article 'Dutch historical sources', Graham Irwin (1965:234-5) ascertained that the Dutch sources - both official and personal - do indeed mostly focus on the colonial government and the life of the Europeans, but they also contain some information about the non-European society. We must consider that the authors sometimes portrayed a rather rosy situation. For example, the assistant-resident of Bankulen would not have been happy with vaccine reports recording many more victims than earlier reports because this would have harmed his chances of promotion. ${ }^{6}$ Godelieve van Heteren is convinced that the judgement of indigenous medicine in the Dutch East Indies offered by Dutch physicians closely reflected their vision of society. In her article 'Which differences will have to go? The variety of physiological differentiations in the colonial context of Java 1860-1900', she named the physician A.G. Vorderman as an example. He was clearly interested in native and Chinese medicine and published articles about them. He accused his colleague C.L. van der Burg, author of the three-volume standard work De geneesheer in Nederlandsch-Indië (The physician in the Dutch East Indies), of castigating the midwives as incompetent and paying too little attention to the role of the dukun (Van Heteren 1996:6).

\footnotetext{
$6 \quad$ Pruys van der Hoeven 1864:21. Pruys suggests that this opinion came from a controleur. It is, however, quite likely that it was his personal opinion.
} 
Only at the end of the nineteenth century did several native men (and women) start writing themselves. They were definitely not representative of their fellow countrymen, the majority of whom were illiterate. An important indigenous source is the Tijdschrift voor Inlandsche Geneeskundigen, which appeared between 1893 and 1922. In the very first issue, the editor C. Eijkman, the director of the dokter djawa school and later Nobel prize winner, described the aim of the periodical: meeting the urgent need of the dokter djawa to keep in touch with his field and expand his knowledge. The school's teaching staff and occasionally a student from the senior class produced the contents. Graduates also sent in case reports from their practice. Aside from this periodical, there were several indigenous sources written by men from the elite, or even the nobility, as memoirs at the end of their lives. Only one, the observations of Soetomo, was set down like a diary throughout the author's career.

Not one source contains original material written by the dukun themselves, the largest group of providers in the medical market. They can definitely be called the silent majority. Luckily, modern medical and cultural anthropology provides useful literature to cover the gap. Clifford Geertz, Parsudi Suparlan and Mark Woodward conducted fieldwork on Java around 1960, 1970 and 1980, respectively. The fieldwork of Roy Jordaan on Madura around 1980 is also relevant for describing the 'market of medical goods and services' in the Dutch East Indies. The question remains, of course, to what extent their findings reflect the Javanese and Madurese in the nineteenth century.

\section{COLONIAL MEDICAL HISTORIOGRAPHY}

The historiography of the medical history of the Dutch East Indies is scarce. We have the reference works of D. Schoute, who was a surgeon by profession, but a historian of medical science by vocation (Schierbeek 1955:78). After his publication about the Dutch East India Company era, De geneeskunde in den dienst der Oost-Indische Compagnie in Nederlandsch-Indië (Medicine in the service of the East India Company in the Netherlands Indies, 1929), he wrote a second standard work, De geneeskunde in Nederlandsch-Indië gedurende de negentiende eeuw (Medicine in the Netherlands Indies throughout the nineteenth century, 1936). Both are still used as works of reference. Schoute described the situation from a Western standpoint, paying considerable attention to the indigenous 
population but little to the indigenous medicine and the dukun. He drew the readers' attention to the progressive ideas and deeds of Willem Bosch as head of the Medical Service. A.H. Borgers elaborated further on this in his thesis, Doctor Willem Bosch en zijn invloed op de geneeskunde in Nederlandsch Oost-Indië (Dr. Willem Bosch and his influence on medicine in the Netherlands East Indies, 1941). In the same year a dissertation was published by a former missionary doctor, J.A. Verdoorn, Verloskundige hulp voor de inheemsche bevolking van Nederlandsch-Indië (Midwifery assistance for the indigenous population of the Netherlands Indies). His approach was dominated by the contact that he had had with the indigenous population. The two other dissertations about the subject published before the Second World War are less relevant for this study (Penris 1930; Boelman 1936).

After a long silence, the thread was picked up by D. de Moulin, professor of the history of medicine in Nijmegen. In the 1980s he was the only scholar interested in the medical history of the Indonesian archipelago (De Knecht-van Eekelen 1989a:1). He supervised a master's thesis (Lauw 1987), which gave a good impression of the first 25 years of the dokter djawa school, and a dissertation (Den Hertog 1991). On the occasion of his 70th birthday, a symposium was organized for him; the papers presented were published in the compilation $N$ ederlandse geneeskunde in de Indische archipel 1816-1942 (Dutch medicine in the Indies archipelago, 1989). Peter Boomgaard, professor at the University of Amsterdam, seems to have taken over from De Moulin. He has written a number of articles about aspects of health care in the Dutch East Indies. Together with Rosalia Sciortino and Ines Smyth, he was the editor of the compilation Health care in Java (1996).

The amount of writing on the medical history of the Dutch East Indies is thus limited and dates partly from before the Second World War. It is all rather traditional historiography, narrative and descriptive in nature. The discussion in the Anglo-Saxon world about medical history writing from the 1980s onwards largely bypassed the medical history of the Dutch East Indies. The missionary doctor Verdoorn forms an exception to this. In his dissertation he places midwifery emphatically in a social context, thereby conducting social medical history avant la lettre. Other exceptions include the article by Susan Abeyasekere (1987) about the medical market in Jakarta in the nineteenth century and the one by Hilary Marland (2003) who, in her description of the strategy with 
which midwives in the Dutch East Indies were employed to civilize the population, drew a parallel with the situation in the Catholic south of the Netherlands. Both regions were considered backwards by the ProtestantChristian political centre.

\section{A NOTE ON SPELLING AND USAGE}

The geographical names employed in the colonial period have been modernized, thus Jakarta for Batavia and its suburb Weltevreden; Bogor for Buitenzorg; Surabaya rather than Soerabaja. For each town or village, the residency is given in parentheses, for example, Kudus (Semarang). The names of institutions, however, have been rendered in their original spelling, thus Vereeniging tot Bevordering der Geneeskundige Wetenschappen in Nederlandsch-Indië (Association for the Advancement of Medical Science in the Netherlands Indies). Just a few Malay terms have been used that are so typical that they are hard to translate, such as dokter djawa. All quotations - as is all the text - are translated by Alison Fisher. Several descriptions, concepts and phrases that appear in this book are reminders of Indonesia's colonial past. This was difficult to avoid in a monograph like this. Given that it is an anachronism to speak of Indonesians in the period covered in this book (1850-1915), the terminology will be used that was common at that time. In those days Indonesians were labelled 'natives' or 'the population'; the latter term is factually incorrect as Europeans and Chinese also formed part of the population. The majority of the Europeans was of mixed descent - the Indo-Europeans - and/or had been born in the Indies. 